\title{
Blastogenic Response in the Rat Lymphocyte Using Glucose Consumption Test
}

\author{
Isao IKARASHI, Naomi SUNOUCHI, Shunji TOYOHARA, \\ and Kiyonori TAUCHI \\ Imamichi Institute for Animal Reproduction, 1103 Fukaya, \\ Dejima-mura, Niihari-gun, Ibaraki 300-01, Japan
}

(Received 25 October 1989/Accepted 19 December 1989)

\begin{abstract}
To estimate the immune function of the rat, the blastogenic response of rat lymphocytes in blood drawn from the vena cava was investigated. The recovery rate of lymphocytes from venous blood was $33.2 \pm 2.23 \%$ and their viability rate was $99.8 \pm 0.25 \%$. Three kinds of mitogens (phytohemaggultinin-M, concanavalin A and pokeweed mitogen) at three different concentrations (high, middle and low) were added to lymphocyte suspensions, and the suspensions were cultured under $5 \% \mathrm{CO}_{2}$ incubation. Cultured suspensions were served for glucose consumption test and values were calculated (glucose consumption test-stimulation ratio (GCT-SR)). Incidence of blast cells was also observed by morphology. In both the GCT-SR and blast cell incidence, the highest values, $41.2 \%$ and $50.8 \%$, respectively, were obtained after stimulation with phytohemaggultinin-M at the concentration of $0.1 \mathrm{ml} / \mathrm{ml}$. The results were statistically analyzed by the variance of means. On both the GCT-SR and blast cell incidence, values obtained in each condition (kind of mitogens on the concentration used) were all statistically significant (all $\mathrm{P}<$ 0.01 ). The correlation coefficient between the GCT-SR values and the blast cell incidence was $0.97(\mathrm{P}<0.01)$. From these results, we concluded that the glucose consumption test using rat blood lymphocytes can be used as a safe and simple method to measure the immune function of rats.
\end{abstract}

\section{グルコース消費試験を用いたラット静脈血 リンパ球幼若化反応の検討}

五十嵐 功・策内直美・豊原俊治・田内清憲

財団法人動物繁殖研究所

生体の免疫機能を検討する場合, ヒト $[6,7]$ を始め とし, ウシ $[9,20]$, ウマ $[24]$, ブタ $[8,22]$, ヒッジ [2], イヌ [12], ネュ [4] 等の家畜においても，リン パ球幼若化能を指標とすることが多い。これらの検討に 使用するリンパ球は，主として末梢血から分離している。 しかし，マウス技よびラットの実験用小動物では, 脾臓 あるいは腸間膜リンパ節などのリンパ器官由来リンパ球
を使用する場合が多く $[5,14,23]$, 静脈血リンパ球を使 用して幼若化反応をみた報告はなく，prostaglandin 合成を調べた報告 [17] があるのみである。

リンパ器官からリンパ球を分離する方法は, リンパ球 収量が多いといら利点がある反面, 分離時間および細胞 の生存率の点で問題がある [18]。また, リンパ球幼若 化反応の成績判定法として, 形態学的観察法, 放射性物 
質の取り込み測定による方法および培地中のグルコース 消費量の測定による方法がある [22]。これらの方法の らち, 形態学的観察法は, 経済的ではあるが, 多量の血 液と成績判定に熟練を要し，再現性と客観性に難点があ り，多数検体処理は困難とされている。また，放射性物 質を使用する方法は, 高価な装置と設備が必要であると ともに，放射能污染対策も問題となる。しかし、グルコ 一ス消費試験法は, 測定装置があれば, 微量の血夜で測 定可能であり, しかも判定が容易で再現性と客観性が良 好であり, 多数検体の処理が可能とされている。

ラットのような小動物でリンパ球幼若化能を検討する 場合, 微量の血液を用い, しか子多数の検体を容易に処 理できることが望ましい。そこで著者らは、リンパ球が 多いといわれている静脈血 [13] からリンパ球を回収し て培養し、リンパ球幼若化誘発に用いられることが多い 3 種類の mitogen について, それらの濃度とグルコー ス消費量の関係を検討した。また，グルコース消費試験 の成績の妥当性を確認するため, グルコース消費量と培 養りンパ球のギムザ染色標本の形態学的観察から算出し た幼若化細胞出現率との関係を検討した。

\section{材料および方法}

供試動物：Wistar-Imamichi ラット10週龄 今 5 匹 を、リンハ球採取用動物として供試した。これらのラッ 卜は, 室温 $24 \pm 2{ }^{\circ} \mathrm{C}$, 湿度 $55 \pm 10 \%$, 換気回数 $12 \sim 15$ 回 $/ \mathrm{hr}$, 照明時間は $5 \sim 19$ 時の14時間, ケージは金網製, 飼料(船橋農場 $\mathrm{MM}-3$ ) および飲料水（自家水道水） は自由拄取の条件下で飼育した。

リンパ球の分離：Ficoll-conrayを用いた比重遠心 法[19]で行なった。分離剂は, Ficoll 400 (Farmacia) $9 \mathrm{w} / \mathrm{v} \%$ 水溶液と Conray 400 (第一製薬) $33.3 \mathrm{v} / \mathrm{v}$ \%水溶液を24:10の割合で混合し（此重1.078）, スター ラーで 1 昼夜㧥䢁啳, 高圧蒸気隇菌したものを使用した [18］。すず，供試ラットをェーテル麻酔し，へパリン （ノボインダストリーA/S）濃度 $30 〜 50 \mathrm{unit} / \mathrm{ml}$ とな るように後大静脈から $8 \mathrm{ml}$ ずつ採血した。このうち 1 $\mathrm{ml}$ を血液学的検查に供し, 白血球数および白血球百分 比を算定した。残り $7 \mathrm{ml}$ の血液をDulbecco's PBS (一)で 2 倍希积し, 高圧蒸気减菌したリンパ球分離用鉄 カルボニール (iron carbonyl, 和光純薬) $40 \mathrm{mg} / \mathrm{ml}$ 濃度に加えた。これを $37^{\circ}$ Cで 1 時間培養して鉄紛を単球 に負食させ，Ficoll-conrayに静かに重層し，1800rpm 20分間遠心分離し、リンパ球浮遊原液を作製した [15]。 この浮遊原液をPBS (一) で 3 回洗浄後, 培養液でリ
ンパ球濃度 $2 \sim 3 \times 10^{6}$ 個 $/ \mathrm{ml}$ に調製し、リンパ球浮遊 液として滅菌ミクロスピッッ（日本バイオテック）にそ れぞれ $1 \mathrm{ml}$ ずつ分注し, 密閉保存した。

培養方法：リンハ球浮遊液に培盖液之所定湿度の mitogenを加え， $37^{\circ} \mathrm{C} て ゙ 96$ 時間炭酸ガス培養した。培着液 は，RPMI-1640（ニッスイ）を基礎培㽰液とし，これ に HEPES (N-Hydroxyethyl-piperazine-N'-2-ethan

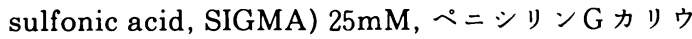
ム（明治） $100 \mathrm{unit} / \mathrm{ml}$, 硫酸ストレプトマイシン（明 治） $0.2 \mathrm{mg} / \mathrm{ml}$, ラット血清 $0.1 \mathrm{ml} / \mathrm{ml}, 10 \%$ 重炭酸ナト リウム（和光純薬） $0.04 \mathrm{ml} / \mathrm{ml}$ の割合で添加したもの を用いた。なおラット血清は, Wistar-Imamichi SPF ラットす 10 週龄を炭酸ガス麻醉し, 腹大動脈から無菌的 に採血し， $3000 \mathrm{rpm} \mathrm{10}$ 分間遠心分離後， $56^{\circ} \mathrm{C} 30$ 分間非 働化した。

Mitogen : Phytohemaggultinin-M (PHA-M, 50 $\mathrm{mg} / \mathrm{ml}, \mathrm{DIFCO}$ ), concanavalin A (ConA, SIGMA) および pokeweed mitogen (PWM, Biosys, S. A.) を使用した。ただし、添加湦度は 3 段階 (high, middle および low) すなわち PHA-M は0.2，0.1および0.05/ $\mathrm{ml}, \mathrm{ConA}$ および PWM は20, 10, および $5 \mu \mathrm{g} / \mathrm{ml}$ と なるように培養液に加えた。

グルコース消費量の側定 : グルコース消費量 $[3,16]$ を用い,リンパ球培養液遠心上清中のグルコース浱度を 測定した。すなわち，培養液を1000 rpm で10分間遠心 分離し, hexokinase を用いた酵素法によりアンコール アナライザーで遠心上清中のグルコース濃度を測定し， 次式により,グルコース消費量から求めた刺激率 (GC T-SR）を求め, 幼若化の指標とした。

$$
\text { GCT }- \text { SR }=\frac{\text { Gcont-Gstim }}{\text { Gcont }} \times 100 \%
$$

ただし，

GCT-SR : glucose consumption test stimulation ratio

Gcont : gluccose concentration in control culture

Gstim : glucose concentration in stimulation culture

幼若化細胞の出現率: 培着細胞を $3: 1$ メタノール酢 酸により固定後塑枺し，pH6.8の PBS（一）で40倍希 釈したギムザ夜で 5 分間染色し, 培養細胞を200個以上 数え, 次式により幼若化細胞 (blast cell) の出現率を 算出した。 
Table 1. Total leucocytes counts, lymphocytes ratio and lymphocyte count from rat venous blood

\begin{tabular}{cccc}
\hline Rat no. & $\begin{array}{c}\text { Total leucocyte count } \\
\left(\times 10^{2} / \mathrm{mm}^{3}\right)\end{array}$ & $\begin{array}{c}\text { Lymphocyte ratio } \\
(\%)\end{array}$ & $\begin{array}{c}\text { Lymphocyte count } \\
\left(\times 10^{2} / \mathrm{mm}^{3}\right)\end{array}$ \\
\hline 1 & 89 & 92.1 & 82 \\
2 & 104 & 89.4 & 93 \\
3 & 98 & 91.8 & 90 \\
4 & 83 & 81.9 & 68 \\
5 & 114 & 92.1 & 105 \\
\hline Mean & 97.6 & 89.5 & 87.6 \\
S. D. & 12.2 & 4.4 & 13.7 \\
\hline
\end{tabular}

Table 2. Values of GCT-SR after stimulation with mitogens at three concentrations

\begin{tabular}{lccc}
\hline mitogen & \multicolumn{1}{c}{ high $^{1)}$} & middle $^{2)}$ & low $^{3)}$ \\
\hline PHA-M & $35.7 \pm 10.61 \%{ }^{4)}$ & $41.2 \pm 7.55 \%$ & $33.3 \pm 3.94 \%$ \\
ConA & $23.8 \pm 6.46$ & $11.9 \pm 4.78$ & $2.1 \pm 1.55$ \\
PWM & $5.6 \pm 4.35$ & $3.8 \pm 3.23$ & $8.3 \pm 6.70$ \\
\hline
\end{tabular}

1) PHA-M $: 0.2 \mathrm{ml} / \mathrm{ml}$, ConA and PWM $: 20 \mu \mathrm{g} / \mathrm{ml}$

2) PHA-M $: 0.1 \mathrm{ml} / \mathrm{ml}$, ConA and PWM $: 10 \mu \mathrm{g} / \mathrm{ml}$

3) PHA-M $: 0.05 \mathrm{ml} / \mathrm{ml}$, ConA and PWM $: 5 \mu \mathrm{g} / \mathrm{ml}$

4) Mean \pm S. D.

$$
\text { 幼若化細胞の出現率 }=\frac{\text { 幼若化した細胞数 }}{\text { 観察した培養細胞数 }} \times 100 \%
$$

データの解析：GCT-SR 值技よび幼若化細胞の出現 率のデータ解析は, mitogen の種類 (PHA-M, ConA, PWM) および mitogen の濃度 (high, middle および low)を要因とし，繰り返しのある 2 元配置法の分散分 析で行なった。ただし出現率の解析は，生の出現率デー タおよび正規分布により近似させるため逆正弦変換した 出現率の両者について解析した。なお，統計的に有意と なった各要因および 2 要因間交互作用については, 水 準平均値間の詳細な比較を Tukey の方法で行なった [25]。また, 各 mitogen の各浱度における GCT-SR 値と幼若化細胞出現率間の相関係数を計算し, 相関図を 作製した。

\section{成}

Table 1 に, Wistar-Imamichi ラット10週龄 $05 匹$ の静脈血の白血球数, 白血球百分比およびそれらから算 出したリンパ球数を示した。なお，リンパ球浮遊液中の リンパ球数と Table 1のリンパ球数から算出したリン
パ球回収率は33. 2 土2.23\%であり，その生存率は 99.8 $\pm 0.25 \%$ であった。

Table 2 に, 各 mitogen の各溶度に护ける GCT-SR 値の平均値および標準偏差を示した。

PHA-M では, middleの平均值が最大で, low が最 小である。ConA では，平均値の大きさは濃度の濃い 順と一致し, high が最大で, low が最小である。PWM では, どの濃度の平均值も小さいが, low が最大で, middle が最小である。また全体としては, PHA-M の

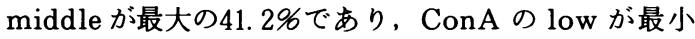
の2.1\%である。分散分析の結果, mitogen の種類間の 差, mitogen の濃度間の羑および両者の交互作用は,

いずれも $1 \%$ の危険率で有意であった。

分散分析の結果が有意のため, mitogen の種類およ び濃度ごとの平均值について，すべての組合せでふたつ の平均値間の羑の検定を行った。Fig. 1 亿，検定結果 を階段図として示した。PHA-M では, high と middle 間に $5 \%$ の危険率で, middle と low 間に $1 \%$ の危険 率で有意差が認められているが，high と low 間には有 意差がない。ConAでは，各濐度間にいずれも1\%の 危険率で有意差が認められている。PWM では，各濃度 間に有意差がない。また，PHA-M の各浱度の平均値 


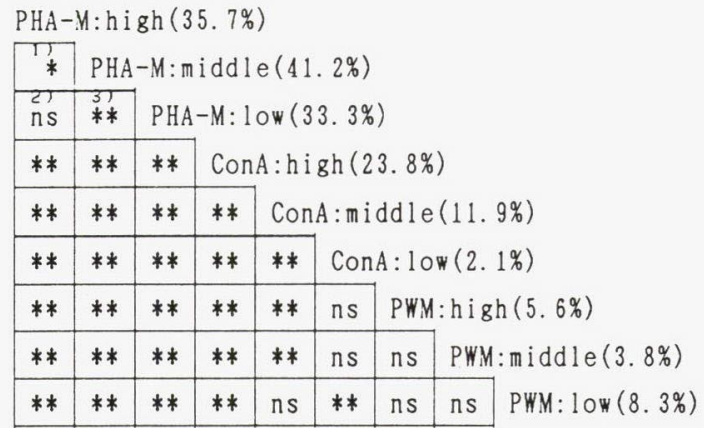

ns : no significant difference * : significant difference at a $5 \%$ level **: significant difference at a $1 \%$ level

(): mean of GCT-SR(\%) 1) Significant difference at a $5 \%$ level between the mean of GCT-SR(\%) from PHA-M:high and that from PHA$M: m i d d l e$ 2) No significant difference between the mean of GCTSR (\%) from PHA-M: high and that from PHA-M:low 3) Significant difference at a $1 \%$ level between the mean of GCT-SR (\%) from PHA$\mathrm{M}: \mathrm{middle}$ and that from PHA-M:low, and so on

Fig. 1. Summation of statistical difference of means of GCT-SR values in Table 2 (by Tukey's method)

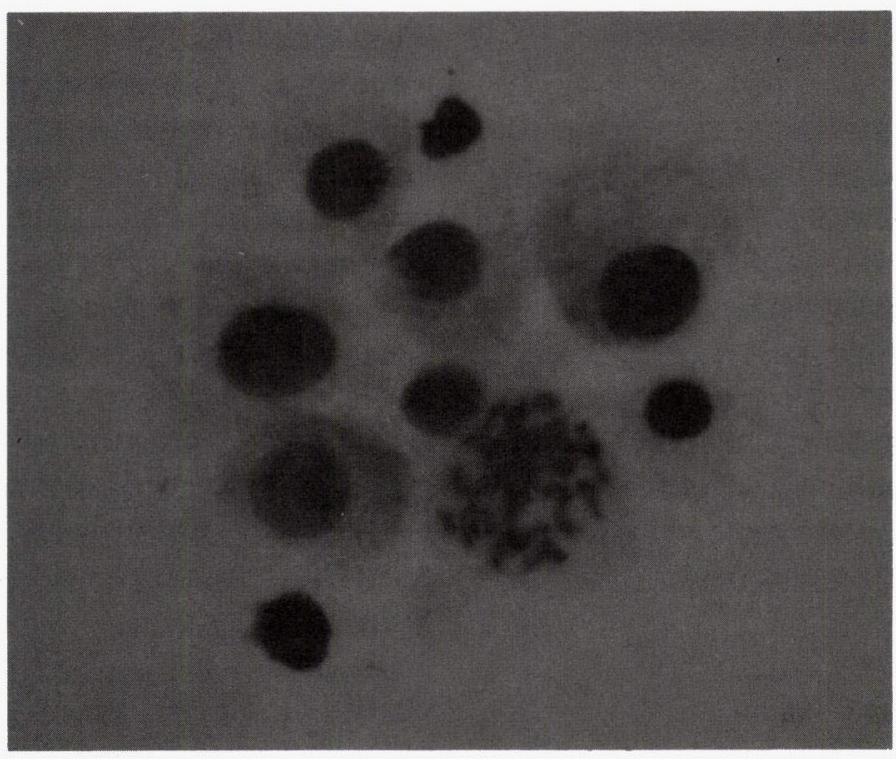

Fig. 2. Blast cells and karyoschisis in lymphocyte culture after stimulation with a mitogen (PHA-M) at $0.1 \mathrm{ml} / \mathrm{ml}$ 
Table 3. Incidence of blast cells after stimulation with mitogens at three concentrations

\begin{tabular}{lllr}
\hline mitogen & \multicolumn{1}{c}{ high } & \multicolumn{1}{c}{ middle } & low \\
\hline PHA-M & $47.0 \pm 9.70 \%$ & $50.8 \pm 6.65 \%$ & $36.8 \pm 8.11 \%$ \\
ConA & $31.6 \pm 7.70$ & $20.4 \pm 5.59$ & $7.4 \pm 2.30$ \\
PWM & $22.6 \pm 4.68$ & $19.1 \pm 4.10$ & $24.3 \pm 6.47$ \\
\hline
\end{tabular}

see the footnotes in Table 2 .

\begin{tabular}{|c|c|c|c|c|c|c|c|c|}
\hline ns & \multicolumn{8}{|c|}{ PHA-M:middle $(50.8 \%)$} \\
\hline ** & ** & \multicolumn{7}{|c|}{ PHA-M: 1 Ow $(36.8 \%)$} \\
\hline ** & ** & ns & \multicolumn{6}{|c|}{ ConA: high $(31.6 \%)$} \\
\hline ** & ** & ** & ** & \multicolumn{5}{|c|}{ ConA:middle $(20.4 \%)$} \\
\hline ** & ** & ** & ** & $* *$ & \multicolumn{4}{|c|}{ ConA: low $(7.4 \%)$} \\
\hline ** & ** & ** & ** & * & ** & \multicolumn{3}{|c|}{ PWM:high (22.6\%) } \\
\hline ** & ** & ** & ** & ** & $\mathrm{ns}$ & ns & PWM & middle $(19.1 \%)$ \\
\hline ** & ** & ** & ** & ns & ** & ns & ** & PWM: 10w (24.3\%) \\
\hline
\end{tabular}

see also the footnotes in Fig. 1.

Fig. 3. Summation of statistical difference of means of incidence of blast cells in Table 3 (by Tukey's method, Analysis was made with original values (appeared in parenthesis) were transformed into inverse sine values.)

とも, ConA および PWM のどの濃度の平均值よりも 大であり,いずれる $1 \%$ の危険率で有意差が認められて いる。しかし, ConA の high と middle の平均値は, PWM のどの覈度の平均值よりも大であるが, ConA の high と PWM の low 間には有意差は認められない。 また, ConAの low の平均値が最小であるが, PWM の high 間および middle 間に有意差がなく，PWM の low 間に $1 \%$ の危険率で有意差がある。

Fig. 2に, mitogen 添加培養による幼若化細胞拉よ び細胞分裂中期像を示した。幼若化細胞では，核と細胞 質の著明な巨大化を認めた。

Table 3に, 各 mitogen の各濃度に扣ける幼若化細 胞の出現率の平均値および標準偏差を示した。各 mitogen 各浱度に打ける出現率の関係は, Table 1のGCTSR 値の場合とほぼ同様である。全体としては, PHAM の middle が最大の50.8\%であり, ConA の low が 最小の7.4\%である。出現率の生の值および逆正弦変換 した出現率の分散分析の結果, いずれも GCT-SR 值の 場合と同様で, mitogen の種類間の差, mitogen の濃
度間の差および両者の交互作用は，いずれも $1 \%$ 危険 率で有意であった。

Fig. 3 に, Fig. 2 と同様の処理を行った検定結果を 階段図として示した。ただし括弧内には，出現率の生の 值の平均値を示した。PHA-M では, high と middle 間に有意差がないが, high と low 間および middle と low 間に $1 \%$ の危険率で有意差が認められている。 ConA では, 各濃度間にいずれも5\%または $1 \%$ の危 険率で有意差が認められている。PWMでは, high と middle 間技よび high と low 間に有意差がないが, middle と low 間に $1 \%$ の危険率で有意差が認められ ている。また, PHA-M 各濃度の平均値とも, ConA および PWM のどの濃度の平均値よりも大であり， PHA-M の low と ConA の high 間に有意差がないが, 他はいずれも1\%の危険率で有意差が認められている。 ConA の各濃度と PWM の各濃度との関係も, GCT-SR 值の場合と若干異なっている。

Fig. 4 K, 各 mitogen の各濃度における GCT-SR 値（\%) と幼若化細胞出現率を, 同一平面上にプロット 


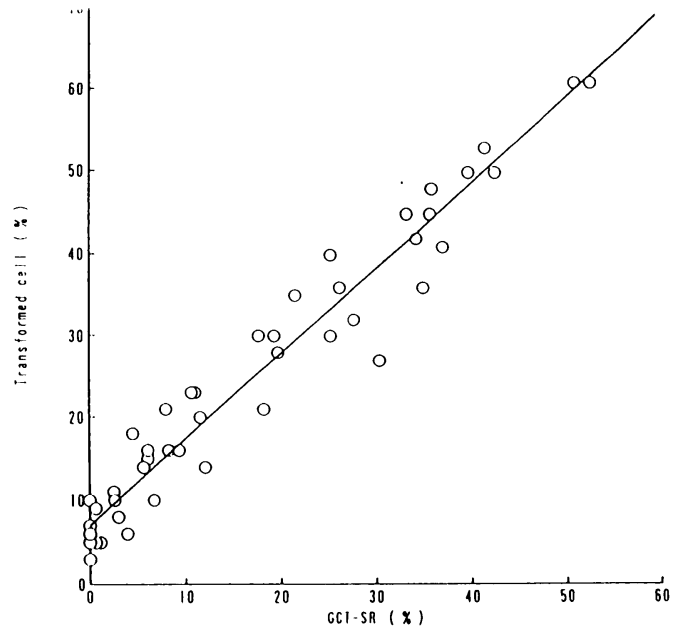

Fig. 4. Correlation between GCT-SR value and the incidence of blast cells

した相関図を示した $(\mathrm{n}=50)$ 。相関係数 $\mathrm{r}$ は0.97（ $\mathrm{P}$

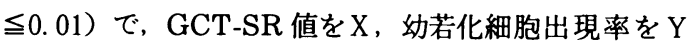
とすると回㷌直線 $Y=1.04 X+6.98$ が得られた。

\section{考寮}

今回我々は, 従来ラットのリンハ球培養実験系でほと んど用いられなかった静脈血リンハ球を材料とし, 幼若 化能に関する一連の検討を行なった。その結果, 後大静 脈から採血し静脈血からのリン八球の回収率技よびその 生存率は比較的良好であった。したがって、ラットのよ らな実験用小動物においても，上トおよび各種家畜の場 合と同様に, 静脈血由来リンパ球の培養が十分可能と思 われる。

グルコース消費試験は，すでにヒトにおける日常検査 法 [6] として確立されている。リンパ球の幼若化能を 調べる正確な方法として，放射性同位元素の ${ }^{3} \mathrm{H}[1,26]$ あるいは蛍光色素の ethidium bromide [10]を用い て判定する方法がある。しかしグルコース消費試験は，

放射性物質あるいは特別な装置や施設を必要としない 点で安全かつ簡便な方法といえる。また今回得られた GCT-SR 値は, 形態学的に調べた各種 mitogen の幼 若化細胞出現率との間で強い相関関係が認められ, 成績 の一致度が高かった。したがって, ラットの実験系にお いても,グルコース消費量を指標にし，微量の血夜を用 いて多数検体の幼若化能を判定し, 各種の比較検討が容
易にできるものと思われる。

今回使用した 3 種の mitogen のらち, PHA-M と ConA は T-cell 刺激, PWM は B-cell 刺激 mitogen といわれている。GCT-SR 值から推定したリンパ球幼 若化能に対する各 mitogen の最適濃度は, PHA-M で は $0.1 \mathrm{ml} / \mathrm{ml}$, ConA では20 $\mu \mathrm{g} / \mathrm{ml}$ であった。しかし PWM では, 各濃度とも幼若化能が低く, しかも濃度間 に有意差がなかった。今後さらに，PWM の異なる濃度 あるいは他の B-cell 刺激 mitogen についても検討する 必要があると思われる。

\section{要約}

ラット静脈血由来リンパ球を幼若化反応に利用するた め, 後大静脈から採取した静脈血からリンパ球を回収し た。リンバ球の回収率は $33.2 \pm 2.23 \%$ であり, その生存 率は99. $8 \pm 0.25 \%$ であった。このリンパ球浮遊液に 3 種 類の mitogen (phytohemaggultinin-M, concanavalin A および pokeweed mitogen) の各 3 濃度を加兄 て炭酸ガス培養し、グルコース消費試験によるGCT-SR 值 (glucose consumption test-stimulation ratio) および形態学的に測定した幼若化細胞の出現率を求め, mitogen の種類およびそれらの濃度の影響を検討した。 その結果, GCT-SR および幼若化細胞の出現率に与え る mitogen の種類とそれらの濃度の影響および両者の 交互作用は，いずれも1\%の危険率で梳計的に有意であ ク, phytohemaggultinin の0.1ml/ml の GCT-SR 值 および奻若化細胞の出現率が最大で，それぞれ $41.2 \%$ お よび50.8\%であった。また，GCT-SR 值と幼若化細胞 の出現率との間に相関係数 $\mathrm{r}=0.97$ といら強い相関関係 が得られ, 両者の成績の一致度が高かった。したがっ て, ラットの静脈血由来リンパ球を用いるグルコース消 費試験により, 安全かつ簡便にしかも微量の血液で多数 検体について、リンパ球の幼若化能を調べることが可能 である。

稿を終えるに臨み終始親切な御指導，御校閲を賜った財団法 人動物繁殖研究所副所長滝沢隆安博士に深謝いたします。ま た，本論文作成に御協力をいただいた、コンピュータ室長今井 節夫氏および第四研究部研究員五十嵐洋氏に感謝します。

\section{文 献}

[1] Bach, F. H. and Voynow, N. K. (1966). One-way stimulation in mixed leukocyte culture. Science, 153, 545-547.

[2] Burrelles, C., Wells, P. W., and Sutherland, A D. (1978). Reactive of ovine lymphocyte to phytohemaggulutinin and pokeweed mitogen during preg- 
nancy and in the imediate post-parturient period. Clin Exp Immunol, 33, 410-415.

[3] Decock, W., Decree, J., Van Wauwe, J., and Verhaegen, H. (1980). Measurement of mitogen stimulation of lymphocytes with a glucose consumption test. J. Immunol Method, 33, 127-131.

[4] Goituka, R., Hirota, Y., Hasegawa, A., and Tomoda, I. (1987). The decline in the production of interleukin 2 in cats spontaneously infected with feline leukemia virus. Jpn J. Vet. Sci. 49, 7-14.

[5] Hornicek, F. J., Reese, D. H., Lo, H. K., Malinin, T. I., and Malinin, G. I. (1988). Periodic acid induced blastogenesis of lymphocytes is independent of phosphoinositide turnover. Biochem Biophys Commun, 154, 606-612.

［6］伊保澄子・倉 文明・星野 孝 (1983)。グルコース消 費試験による PHA 幼若化率の判定. 免度実験操作法XI. pp. $4123-4126$, 日本免疫学会編.

［7]伊保澄子・星野 孝・高橋隆幸（1983）。 PHA 幼若化反 応に対する人抑制性 T細胞の簡易測定法．免疫実験操作 法XII.pp. 4127-4132, 日本免疫学会編.

[8] Inoue, T., Tsukamoto, H., Goto, N., and Matsumura, K. (1987) . Application of ethidium bromide fluorescence assay to measurement of blastogenesis of swine lymphocytes. Jpn. J. Vet. Sci, 49, 681-686.

[9] Ishikawa, H. (1987). Obserbation of lymphocyte function in perinatal cows and neonatal calves. Jpn. J. Vet. Sci, 49, 469-475.

１10］伊藤善久・河合 忠（1983）。エチジウムブロマイド蛍 光法を用いたリンパ球幼若化反応試験の基檚的検討及び 臨床応用. 臨床検査, 27，928-931。

［11］河合 忠 - 近藤泰正・河野均也・賀屋秀男 (1970)。 リ ン八球幼若化反応の検索. 臨床検查, 14，1422-1428.

[12] Kudo, T., Kato, Y., Masuno, H., Honjo, H., and Kitazawa, K. (1987). The effect of repeated acupuncture stimulation on canine lymphocyte response. Jpn J. Vet. Sci, 49, 1009-1013.

［13］国枝哲夫・黒澤 努・杉山芳宏・花上 上・今道友則・ 四方疸一 (1987)。ラットに护ける動脈血, 静脈血間の リンパ球サブポピュレーションの比較. 実験動物， 36, 109-116.
[14] Locniskar, M., Nauss, K. M., and Newberne, P. M. (1983). The effect of quality of dietary fat on immune system. J. Nutr., 113, 951-961.

[15] Lohrmann, H-P., Novikovs, L., and Graw, R. G. J. (1974). Stimulatory capacity of human Tand B lymphocytes in the mixed leukocyte culture. Nature, 250, 144-146.

[16] MacHaffie, R. A. and Wang, C. H. (1967). The effect of phytohemaggulutinin upon glucose catabolism in lymphocytes. Blood, 29, 640-646.

[17] Marshall, L. A. and Johnston, P. V. (1985). The influence of dietaly essential fatty acids on rat immunocompetent cell prostaglandin synthesis. $J$. Nutr., 115, 1572-1580.

［18］村上正人・沢田梅彦（1985）。リンパ球分離法。細胞性 免疫機能のすべて, pp 72-76, 月刊 Medical Technology 編，医歯薬出版，東京.

[19］中川俊郎 (1979). リン八球検查. 1 . 分離法. 臨床検 查, 23, 1101-1105.

[20] Nagahata, H., Noda, H., and Abe, T. (1987). Changes in blastogenic response of bovine acute clinical mastitis. Jpn J.Vet. Sci. 49, 1148-1150.

[21］岡部龍也・土屋達行 (1985). リンパ球培養検查. A . 培養方法と成樍判定法. 細胞性免度機能のすべて, pp 162-170，月刊 Medical Technology 編，医歯薬出版， 東京.

[22] Onyekaba, C. (1988). DNA repair in lymphocytes from humans and rats with chronic iron overload. Microbiologica, 11, 201-205.

[23] Pietorangelo, A., Cossarizza, A., Monti, D., Ventura, E., and Franceschi, C. (1988). In vitro blastogenesis of porcine peripheral blood lymphocytes. Biochem Biophys Res Commun, 154, 698-704.

[24] Tajima, M., Fujinaga, T., Koike, T., Okamoto, Y., and Otomo, K. (1987). Assay for equine peripheral blood lymphocytes blastogenic response using ethidium bromide. Jpn J. Vet. Sci., 49, 567-570.

[25] 滝沢隆安 (1985). 獣医応用統計学. pp 153-156, 学空 社, 東京.

［26］士屋達行・河野均也（1979）。芽球化反応，臨床検查， 23, 1110-1114. 